\title{
Endoscopic Dacryocystorhinostomy: Our Experience
}

\author{
1Jyothi A Chavadaki, ${ }^{2}$ Ajay K Manvikar, ${ }^{3} \mathrm{BH}$ Shrikrishna
}

\section{ABSTRACT}

Purpose: To determine the outcome and safety of endoscopic dacryocystorhinostomy (ENDO-DCR) with the use of silicon stents in nasolacrimal duct obstruction (NLDO).

Materials and methods: This study was done in the Department of Otorhinolaryngology and Head and Neck Surgery, Navodaya Medical College, Raichur, from January 2013 to June 2015 , with a total of 82 cases (10 cases with bilateral disease) who underwent a standardized procedure, with an endonasal approach to the lacrimal sac, surgical removal of nasal mucosa, lacrimal bone, and a fragment of the frontal process of the maxilla. The medial wall of the lacrimal sac was removed completely and canalicular silicone intubation tube was placed for 6 weeks postoperatively.

Main outcome measures were resolution of epiphora, absence of discharge, and patency of the ostium confirmed by irrigation and endoscopic evaluation of neo-ostium at 6 weeks.

Results: The ENDO-DCR procedure with adjunctive canalicular silicone intubation tube was successful in 78 (95\%) cases. No significant complications were encountered during or after the operative period.

Conclusion: Endoscopic dacryocystorhinostomy with canalicular silicon intubation for shorter duration (6 weeks) is a safe and successful procedure for the treatment of NLDO in adults as well as in children, with a success rate of $95 \%$.

Keywords: Endoscopic dacryocystorhinostomy, Lacrimal sac, Nasolacrimal duct obstruction, Neo-ostium, Silicone intubation tube.

How to cite this article: Chavadaki JA, Manvikar AK, Shrikrishna BH. Endoscopic Dacryocystorhinostomy: Our Experience. Clin Rhinol An Int J 2017;10(2):49-52.

Source of support: Nil

Conflict of interest: None

\section{INTRODUCTION}

Primary acquired nasolacrimal duct obstruction (NLDO) is a common cause of epiphora in adults, and it is four to five times more common in females. ${ }^{1}$ Many factors were considered in the etiology of acquired NLDO, chronic inflammation being the most popular one. ${ }^{2}$ Local trauma,

\footnotetext{
${ }^{1,3}$ Professor, ${ }^{2}$ Postgraduate Student

${ }^{1-3}$ Department of Otorhinolaryngology-Head and Neck Surgery Navodaya Medical College, Raichur, Karnataka, India

Corresponding Author: Ajay K Manvikar, Postgraduate Student, Department of Otorhinolaryngology-Head and Neck Surgery, Navodaya Medical College, Raichur, Karnataka, India Phone: +918473252985, e-mail: ajaymanvikar@gmail.com
}

iatrogenic causes, including complications of maxillary sinus surgery, rhinoplastic surgery, and midfacial fracture repair were assumed to be some other causative factors. ${ }^{2}$

Since $1904,{ }^{3}$ the surgical management accepted for this disease was the external approach, although Caldwell ${ }^{4}$ was the first to propose, in 1893, the endonasal approach.

Closure of the rhinostomy opening was considered a major factor for surgical failure in external dacryocystorhinostomy (DCR). In external DCR, several methods, such as use of silicone stent and application of mitomycin$\mathrm{C}$ to the rhinostomy opening and suturing of the mucosal flaps have been suggested for providing a permanent rhinostomy opening after completion of mucosal healing. However, in endonasal DCR, insertion of silicone stent is the most commonly preferred procedure. ${ }^{5}$ It has been claimed that silicone stent improves surgical outcomes of endoscopic DCR. On the contrary, some studies indicate that silicone stent itself is a reason for surgical failure due to granulation tissue formation and complications like punctual erosion and slitting of canaliculi.

The present study was undertaken to compare the surgical results of endoscopic DCR with silicone stent for shorter duration (6 weeks).

An external approach was used, in which an incision is made on the skin. The traditional technique-of-choice by ophthalmologists is the order to access the bone, followed by an external osteotomy, opening the nasal mucosa and creating the lacrimal sac flaps from outside to the inside.

The endoscopy-assisted endonasal approach follows the inverse pathway. A nasal mucosa flap is first created, followed by endonasal bone osteotomy to expose the lacrimal sac and its marsupialization to inside the nasal cavity. The endoscopic exposure and view of the entire lacrimal sac is simply fantastic. Success rates of this procedure by both approaches, the external and the endoscopic one, are higher than $90 \%$ in seasoned hands.

The advantages of the endoscopic approach are minor traumatization, preservation of lacrimal pump function, and reduction of surgical time. The success rate of endoscopic DCR is comparable to that of the traditional external procedure, with minimal morbidity and the possibility to treat simultaneous sinonasal diseases. ${ }^{6,7}$

Personal clinical and surgical experiences are herein described and surgical techniques, results, and follow-up of DCR are discussed. 


\section{MATERIALS AND METHODS}

Between January 2013 and June 2015, 72 cases of endoscopic DCR with canalicular silicone intubation tube placement procedures have been performed at the Department of Otorhinolaryngology and Head and Neck Surgery, Navodaya Medical College, Raichur, Karnataka, India.

A diagnosis of NLDO was made from ophthalmic examination. All patients included in the study described epiphora as the major complaint. Documented obstruction on syringing and probing combined with obstruction on lacrimal dacrocystography was used in the diagnosis of NLDO.

Patients with acquired NLDO were informed about endoscopic dacryocystorhinostomy (ENDO-DCR) procedures, the surgical techniques, and the possible complications. Patients with hypersecretion from ocular surface disease, epiphora from lid laxity or malposition, facial nerve weakness, canalicular or punctal stenosis, or obstruction identified on probing, and those with a history of previous nasolacrimal surgery, trauma, tumor or clinically suspected tumor, and granulomatous disease were not included in the study.

Preoperatively, patients underwent an ophthalmic examination including irrigation of the nasolacrimal drainage system, and a preoperative nasoendoscopic evaluation to identify potentially significant intranasal pathology and those with nasal septal deviation in whom a septoplasty might be required. Two patients were found to have septal deviation that was corrected at the time of DCR and one patient had sinus pathology which was managed by preoperative antibiotics and nasal decongestants.

Endoscopic dacryocystorhinostomy was performed by an otorhinolaryngologist. All patients had silicone tubes inserted intraoperatively.

Endoscopic dacryocystorhinostomy was performed under general anesthesia by using standard functional endoscopic sinus surgery instruments and a $4-\mathrm{mm} 0^{\circ}$ rigid Hopkins nasal endoscope. The nasal mucous membrane is incised and removed to allow for the creation of a window on the lacrimal sac and upper nasolacrimal duct. A portion of the lacrimal and maxilla bone is removed by Kerrison's punch, and using a sickle knife, a vertical incision is made in the lacrimal sac and nasolacrimal duct. Silicone tubes can be inserted and knotted to assist long-term patency.

\section{MAIN OUTCOME MEASURES}

Overall outcome was assessed at the first year after surgery, 6 months after removal of the silicone tubes. Subjective success was based on patient's symptoms, objective success on patency with syringing. Subjective success was based on the degree of epiphora, which was graded by the patients as no epiphora ( 0 point), moderate (1 point), and high (2 points). Objective success was determined by a patent nasolacrimal passage confirmed by a normal nasolacrimal lavage. Investigation of the nasolacrimal passage was made by the examination of the ophthalmologist with lacrimal syringing and by the examination of the otorhinolaryngologist with rigid nasoendoscopy to assess appearance of the rhinostomy.

\section{RESULTS}

The findings in 82 patients of chronic dacryocystitis undergoing endoscopic DCR with stent were analyzed. It was observed that the age of patients in the study ranged from 9 to 60 years, with the most common age group affected being 31 to 40 years (36\%). The male to female ratio is 1:2.6. Of the 82 patients, 72 patients had unilateral and 10 patients had bilateral dacrocystitis. The commonest presenting symptom was epiphora, being present in all patients. Other symptoms noted were discharge from the eye in $84 \%$ patients, swelling over the lacrimal sac area in $10 \%$ patients, and lacrimal sac fistula in $6 \%$.

All the patients were subjected to diagnostic endoscopy. Deviated nasal septum to the opposite side was present in two patients. Intraoperative findings were also recorded (Table 1).

Patients were regularly followed at 1, 2, and 6 weeks. Subjective evaluation was made in terms of complete/ partial/no relief from symptoms (Table 2).

Objective evaluation was done by syringing (Table 3 ). Syringing was performed at 1, 2, and 6 weeks and results were evaluated as follows:

- Patent: There was no resistance to the flow of the fluid through sac to nasopharynx.

Table 1: Intraoperative finding

\begin{tabular}{lll}
\hline Findings & No. of cases $(n=82)$ & Percentage \\
\hline Mucoid discharge & 20 & 24 \\
Mucopurulent discharge & 16 & 20 \\
Purulent discharge & 34 & 42 \\
Hypertrophied sac & 10 & 12 \\
Atrophied sac & 2 & 2 \\
\hline
\end{tabular}

Table 2: Postoperative subjective evaluation

\begin{tabular}{llllll}
\hline Epiphora & 1 week & 2 weeks & 6 weeks & 6 months & 1 year \\
\hline No epiphora & $68(83 \%)$ & $75(91 \%)$ & $78(95 \%)$ & $80(97.5 \%)$ & $80(97.5 \%)$ \\
Moderate epiphora & $4(5 \%)$ & $3(4 \%)$ & $2(2.5 \%)$ & $0(0 \%)$ & $0(0 \%)$ \\
High epiphora & $10(12 \%)$ & $4(5 \%)$ & $2(2.5 \%)$ & $2(2.5 \%)$ & $2(2.5 \%)$ \\
\hline
\end{tabular}


Table 3: Postoperative objective evaluation by syringing

\begin{tabular}{llllll}
\hline & \multicolumn{5}{c}{ Period of follow-up } \\
\cline { 2 - 6 } & 1 week & 2 weeks & 6 weeks & 6 months & 1 year \\
\hline Patent & $40(49 \%)$ & $52(63 \%)$ & $78(95 \%)$ & $80(97.5 \%)$ & $80(97.5 \%)$ \\
Partially patent & $30(37 \%)$ & $26(32 \%)$ & $2(2.5 \%)$ & $0(0 \%)$ & $0(0 \%)$ \\
Blocked & $12(14 \%)$ & $4(5 \%)$ & $2(2.5 \%)$ & $2(2.5 \%)$ & $2(2.5 \%)$ \\
\hline
\end{tabular}

Table 4: Endoscopic appearance of neo-ostium

\begin{tabular}{llll}
\hline Wide and patent & Narrow but patent & Obstructed & Total \\
\hline $78(95 \%)$ & $2(2.5 \%)$ & $2(2.5 \%)$ & $82(100 \%)$ \\
\hline
\end{tabular}

- Partially patent: When some of the fluid regurgitated through the upper punctum and some passed into nasopharynx.

- Blocked: When whole of the fluid regurgitated through the upper punctum and no fluid going to the nasopharynx.

Endoscopic evaluation of neo-ostium at the end of 6 weeks was done (Table 4 ) and the status of ostium was categorized as:

- Wide and patent: Neo-ostium is seen clearly wide and patent with flow of fluid through it.

- Narrow but patent: Neo-ostium is visualized but narrow and flow of fluid noted on lacrimal massage.

- Obstructed: Neo-ostium is not visualized and no flow fluid noted on lacrimal massage.

\section{DISCUSSION}

Endoscopic DCR is a commonly performed operation in which a fistulous tract is created between the lacrimal sac and the nasal cavity in order to relieve the epiphora due to NLDO. Silicone stent has been proposed to maintain the patency of fistula during postoperative healing period.

The recent study was undertaken to evaluate and compare the results of endoscopic DCR with the use of silicon stents in nasolacrimal duct obstruction. In our study, complete relief from symptoms was seen in 95\% patients with stent; two patients had partial obstruction due to narrow rhinostomy site by the granulation tissue and in two patients no improvement was found due to closure of rhinostomy due to insufficient osteotomy. Results of our study have been found to be promising as compared with others, with the success rate of $95 \%$. Jin et $\mathrm{al}^{8}$ reported primary success rate of $83 \%$ with endoscopic DCR with stent and in $17 \%$ cases rhinostomy opening was found to be obstructed by granulations or synechie. Sprekelson and Barberán ${ }^{9}$ reported success with endoscopic DCR with stent in $85 \%$ of patients.

Singh et $a 1^{10}$ and Sham and van Hasselt ${ }^{11}$ on the basis of their studies opined that silicone stenting is not routinely indicated in endoscopic DCR. Moreover, silicone stent is associated with high failure rate due to granulomatous inflammation and complications as punctal erosion and slitting of canaliculi. But our study shows good results without complications. The failure rate is less in our study and in only two cases we encountered granulation tissue causing partial obstruction, which was managed successfully by excising the granulation tissue at 6 weeks and the patency of neo-ostium was maintained. Only in two patients, there was failure of DCR due to inadequate osteotomy during surgery, which required a revision surgery.

Most of the study suggests that the stent has to be kept for approximately 3 months, removal before this time is often the cause of failure. Granulation tissue may be detected after 3 months of stenting, ${ }^{12-14}$ but we suggest to keep the stent for 6 weeks postoperatively to prevent complications like granulations, slitting of canaliculi and punctual erosion, fibrosis, and with good success rates of $95 \%$, which is comparable with other studies.

Nevertheless, use of the stent is not well established in the literature. According to some authors, in fact, this procedure is contraindicated on account of an increase in the occurrence of DCR stenosis; ${ }^{15}$ others ${ }^{16,17}$ have described no differences in the success rate using the stent system.

Some authors have described the use of topical applications of mitomycin-C, $0.2 \mathrm{mg} / \mathrm{mL}$ for 25 minutes or 0.5 $\mathrm{mg} / \mathrm{mL}$ for 30 minutes: This antimetabolite reduces scar formation, determining an increase in the success rate of endoscopic DCR. ${ }^{18,19}$ We have no personal experience in the use of mitomycin-C.

\section{CONCLUSION}

Endoscopic dacryocystorhinostomy with canalicular silicone intubation for shorter duration (6 weeks) is a safe and successful procedure for the treatment of NLDO in adults as well as in children with a success rate of $95 \%$. As the duration of the stent in situ is short, the associated complications are very minimal. Hence, we recommend ENDO-DCR with canalicular silicone intubation as one of the safest methods.

\section{REFERENCES}

1. Maini S, Raghava N, Youngs R, Evans K, Trivedi S, Foy C, Mackintosh G. Endoscopic endonasal laser versus endonasal surgical dacryocystorhinostomy for epiphora due to nasolacrimal duct obstruction: prospective, randomised, controlled trial. J Laryngol Otol 2007 Dec;121(12):1170-1176. 
2. Walker RA, Al-Ghoul A, Conlon MR. Comparison of nonlaser nonendoscopic endonasal dacryocystorhinostomy with external dacryocystorhinostomy. Can J Ophthalmol 2011 Apr;46(2):191-195.

3. Toti A. Nuovo metodo conservatore di cura radicale delle suporazioni croniche del sacco lacrimale. Clin Med Firenze 1904;10:385-389.

4. Caldwell GW. Two new operations for obstruction of the nasal duct with preservation of the canaliculi and an incidental description of a new lacrimal probe. NY Med J 1893;57: 581-582.

5. Onerci M, Orhan M, Ogretmenoğlu O, Irkeç M. Long term results and reasons for failure of intranasal endoscopic dacryocystorhinostomy. Acta Otolaryngol 2000 Mar;120(2): 319-322.

6. Presutti L. Endonasal dacryocystorhinostomy. Acta Otorhinolaryngol Ital 1995 Dec;15(6):449-453.

7. Zílelíoğlu G, Tekeli O, Uğurba SH, Akiner M, Aktürk T, Anadolu Y. Results of endoscopic endonasal non-laser dacryocystorhinostomy. Doc Ophthalmol 2002 Jul;105(1):57-62.

8. Jin HR, Yeon JY, Choi MY. Endoscopic dacryocystorhinostomy: creation of a large marsupialized lacrimal sac. J Korean Med Sci 2006 Aug;21(4):719-723.

9. Sprekelson MB, Barberán MT. Endoscopic dacryocystorhinostomy: surgical techniques and results. Laryngoscope 1996 Feb;106(2 Pt 1):187-189.

10. Singh M, Jain V, Gupta SC, Singh SP. Intranasal endoscopic DCR (END-DCR) in cases of dacryocystitis. Ind J Otolaryngol Head Neck Surg 2004 Jul;56(3):177-183.
11. Sham CL, van Hasselt CA. Endoscopic terminal dacryocystorhinostomy. Laryngoscope 2000 Jun;110(6):1045-1049.

12. Soler Machin J, Castillo Laguarta JM, De Gregorio Ariza MA, Medrano J, Cristóbal Bescós JA. Lacrimal duct obstruction treated with lacrimonasal stent. Arch Soc Esp Oftalmol 2003 Jun;78(6):315-318.

13. Bogdănici $C$, Lupaşcu $C$, Halunga $M$. Complications after catheterization of nasolacrimal duct. Oftalmologia 2002;55(4): 39-42.

14. Beloglazov VG, Atokova EL, Malaeva LV, Nikol'skaia GM, Azibekian AB, Saad El'din NM. Intubation granulomas of the lacrimal ducts in patients with silicone implants. Vestn Oftalmol 1998 Sep-Oct;114(5):29-32.

15. Allen K, Berlin AJ. Dacryocystorhinostomy failure: association with nasolacrimal silicone intubation. Ophthalm Surg 1989 Jul;20(7):486-489.

16. Walland MJ, Rose GE. The effect of silicone intubation on failure and infection rates after dacryocystorhinostomy. Ophthalmic Surg 1994 Sep-Oct;25(9):597-600.

17. Unlu HH, Ozturk F, Nutlu C, Ilker SS, Tarhan S. Endoscopic dacryocystorhinostomy without stents. Auris Nasus Larynx 2000 Jan;27(1):65-71.

18. Liu D, Bosley TM. Silicone nasolacrimal intubation with mitomycin-C: a prospective, randomized, double-masked study. Ophthalmology 2003 Feb;110(2):306-310.

19. Camara JG, Bengzon AU, Henson RD. The safety and efficacy of Mitomycin C in endonasal endoscopic laser-assisted dacryocystorhinostomy. Ophthal Plast Reconstr Surg 2000 Mar;16(2):114-118. 